\section{DAVID APTER}

David Apter, with whom, sixty years ago, I enrolled in the graduate program of Princeton University's department of politics, died on May 4 of this year. Along with other graduate students of that era, we shared the conceit that we would change the ways in which the discipline went about doing comparative politics. The moment for striking out in that direction seemed propitious. World War II had introduced countless Americans, among them many future political scientists, to "exotic" countries where political institutions and behavior appeared quite unlike anything they had learned in their undergraduate courses. War itself led to an explosion of interest in nation-reforming in the case of defeated totalitarian systems, and nation-building in those parts of the world where empires were breaking up.

Both World War II and the Cold War that followed in its wake led the Fulbright Program, the Social Science Research Council, and other leading foundations to create grants that permitted graduate students to go abroad to conduct field research-and on a scale and in a range of geographic areas and countries never dreamed of in the pre-war years.

David Apter opted for the Gold Coast, with a stopover on his way at Oxford University's Institute of Colonial Studies. His groundbreaking dissertation was published as The Gold Coast in Transition (Princeton University Press, 1955), a first book that reviewers hailed as a "paradigmatic" work that set new standards as to how in-depth case studies might be conducted. His second book, The Political Kingdom in Uganda: A Study of Bureaucratic Nationalism (Princeton University Press, 1961) not only solidified Apter's growing reputation as a prodigious field researcher with a capacity to use an impressive array of interdisciplinary tools, but it also signaled the presence of a scholar entirely prepared to abandon theories and methods that did not serve him well in his empirical investigations.

One might say about David Apter, as reviewers of his many distinguished works sometimes said or implied, that he never met a theory or approach to research that he didn't like-at least not until he tried it out in his own work. When, as with structure-functionalism, he found theory and method not entirely satisfying, he tried something else. Thus, a short list of the theories and methodological approaches that appear in his oeuvre would include the following: action theory, value theory, symbolic structuralism, development theory, modernization theory, communications theory, normative-ethical analysis, neoinstitutionalism, postmodernism, critical theory, dependency theory, discourse theory, semiotics, and phenomenology. Some reviewers found these shifts irritating, while others praised them as indicators of two of David Apter's most distinguishing intellectual traits-namely, his "unquenchable thirst for information" and his career-long search for a general analytical theory of politics.

The search itself was guided by Apter's conviction that it was a serious intellectual mistake to treat political systems and processes as dependent variables whose evolution and shape are inexorably determined by deeper and more powerful factors located in the social, economic, or broadly "cultural" spheres of societies. He was particularly dubious about theories of political development that, deeply influenced by the Cold War, were severely unilateral as well as ontological in nature, suggesting, for example, that as economic standards of living improved, political systems would tend to become democraticor, to put this more bluntly, that genuine development occurs only when "they" are becoming more like "us."

A quite different way of thinking about the evolution of political systems is spelled out in his The Politics of Modernization (University of Chicago Press, 1965), by far the most widely cited and admired of the more than 20 books that David Apter authored, co-authored, or edited. The book itself marked a second phase in Apter's political science career, one in which he turned his attention to more analytical models of political systems and processes, including what reviewers of this and subsequent works described as "ambitious" and "audacious" attempts to make comparisons across continents as well as countries.

In the preface of this book, Apter notes that in the social sciences, "theories are for burning." He was entirely at ease with what he called "methodological pluralism." In his avid pursuit of this principle, he arguably generated more hypotheses per onethousand words of prose than anyone else in the profession. Agreeing with others that this might also involve statements that were vague and difficult to grasp, one admiring reviewer reminded readers that whatever Apter's thoughts might lack in precision, they gained "in relevancerelevance to social science and to the contemporary world." It is fitting that the contributions of this extraordinary scholar should be appreciated in other disciplines as well, including the humanities.

Reviews of his works appear across a wide spectrum of scientific and intellectual journals. His earliest works, some of them reprinted a half century later, continue to influence the way that case studies about politics are conducted in Africa. For many decades, many of the World Bank's policies regarding that troubled continent have revealed an "Apterian" influence. His books and articles on protest and violence, modernization and globalization, social change, traditionalism, rational choice, primordial political and social systems, American pluralism, industrialization, cultural tensions, and methodologies of comparative research have attracted the attention of scholars representing the widest variety of disciplines.

At Yale, Apter's academic titles included the Henry J. Heinz II Professor of Comparative Political and Social Development, and Senior Fellow in the Center for Comparative Sociology, as well as in the Whitney Humanities Center, of which he was a founder. He also served one term as chair of the university's department of sociology. In 2006, in recognition of the breadth of his intellectual and academic contributions, the International Social Science Council and UNESCO awarded him the Dogan Prize for Interdisciplinary Research.

In 1972, David Apter's Choice and the Politics of Allocation (Yale University Press, 1971) was awarded that year's APSA Woodrow Wilson Award for the best book in political science and international relations. One reviewer saw it as the product 
"of many years of investigation and reflection by one of the world's leading political analysts" and as "clearly an important book." In the profession's leading journal, another reviewer called it "vintage Apter: original and suggestive, sometimes dense and opaque." He then urged graduate students in political science to read all of it, noting that "this book is not only hard reading; it both reflects hard thinking and stimulates hard thinking." This particular book well illustrates Apter's effort to liberate political phenomena from the dependent-on-other-socialeconomic-cultural-historical-or-in-anycase-not-political variables condition in which so many other social scientists, including political scientists, had placed it. Among its many merits, the book shows that "political development" is in great measure a reflection of the types of choices made by the political actors and institutions at different times and under different conditions. The point is that, whatever might be the configuration of these conditions, political leaders are free to choose among broad policy alternatives, each of which will influence the "development" that comes later.

In many of his later writings, David Apter turned his attention to political violence, of which he studied both historical and contemporary examples. In addition to many journal articles on this subject, he wrote, co-authored, or co-edited such books as gainst the State: Politics and Social Protest in Japan (Harvard University Press, 1984), an in-depth study of the longenduring protest movement against the construction of the airport at Narita; Revolutionary Discourse in Mao's Republic (with Tony Saich; Harvard University Press, 1994), a striking analysis of the meaning of Mao's mythic retreat to Ya'nan, where he created a "textual" community of critical importance in the Chinese Communist Revolution; and Political Protest and Social Change: Analyzing Politics (with Charles Andrain; Macmillan, 1995), which probes and illustrates the range of policy responses open to governmental power holders who confront organized protest, as well as the conditions that bring protest itself into existence. His edited The Legitimization of Violence (Macmillan, 1997), which deals with the origins of political violence; in it, Apter argues brilliantly against the egregiously simplistic postmodernist claim that social reality cannot be explained.
It is in this particular sector of his multifaceted intellectual output that one can find the more humorous and sardonic Apter that I knew for many years. A fine example would be his treatment of the psychobabble that so many social scientists and humanist scholars produced in their interpretations of the university student protest movements in the United States and abroad.

David Apter influenced several generations of students and colleagues not only at Yale, where we, his colleagues, enjoyed four decades of his presence. He is also remembered as a distinctive intellectual force at Northwestern, Chicago, and California (Berkeley), where he held professorships. In addition to his research in Africa, Asia, Latin America, and Europe, his lectures, visiting university appointments, and participation in professional associations and conferences took him to literally dozens of countries and cities worldwide. The breadth of his reading and knowledge, the facility with which he generated and elucidated concepts and hypotheses, and the boldness (as well as the playfulness) with which he articulated and defended his ideas about politics and society dazzled everyone, including those who might disagree with him.

During the many decades that David Apter and I shared as students, researchers, and teachers of political science, as colleagues at Yale, and, above all, as friends, he often lamented the emergence, arguably for the first time at Berkeley, of the "multiversity." He saw the latter as engaged in a reckless slicing and packaging of learning and knowledge into too many distinctive and separated organizational units. He saw and wrote about this process as one probable cause of the student revolts of the 1960s. It was in part this fragmentation that intensified his search for a political science that would span several disciplines.

It is the oldest of clichés to remark that they don't make them like that anymore, but all of us who knew David or read his many works, understand that this is exactly the case. David Apter's wife Eleanor, his children Emily and Andrew (both of them distinguished academics), his former students and colleagues, and the political and other social science professions will deeply miss his presence amongst us.

Joseph LaPalombara Yale University

\section{GARY C. BRYNER}

Professor Gary C. Bryner passed away on March 10, 2010, at age 58. Gary courageously faced the challenge of pancreatic cancer with more concern about his wife, family, and friends than for himself. Gary personified the ideal colleague. He was unfailing in his willingness to assist others with their research and was a devoted teacher. He was always first to volunteer when help was needed. Although the cancer progressed quickly, he was grateful for the time he could spend after the diagnosis with his wife, his three children and their spouses, and his three grandchildren.

Gary grew up in Salt Lake City, Utah, graduating from the University of Utah with a BA and MA in Economics. He taught high school in Salt Lake City before pursuing further graduate study in political science at Cornell University. His thinking and writing about politics was especially influenced by Professor Ted Lowi, whom Gary considered a mentor. He was a Brookings Institution Fellow in Governmental Studies in 1981-82. He completed his Ph.D. in 1982, the same year he accepted a faculty position at Brigham Young University. At BYU, Professor Bryner directed the public policy program and taught courses in public policy and American government.

Professor Bryner was a committed scholar. He remained current in his specializations and pushed himself to acquire new knowledge. A Ph.D. was not enough for him. While teaching a full load, he completed a law degree at the BYU Law School. He then used this additional advanced training in his teaching and research.

Bryner authored or edited 15 books, scores of articles and book chapters, and many academic papers. His commitment to scholarship was remarkable. His first book was Bureaucratic Discretion: Law and Policy in Federal Regulatory Agencies, which reviewer W. P. Browne described as a "skillfully written and analytical look at bureaucratic regulation" (Browne 1988, 964). His later work focused on environmental and public land policy, welfare reform, and the Constitution. His most consequential publications were his books, but his articles appeared in the Political Science Quarterly, Policy Studies Journal, Review of Policy Research, and several law reviews.

His work in the area of public lands and environmental policy is perhaps best known. In 1995 he published Blue Skies, Green Politics: The Clean Air Act of 1990 